\title{
PENERAPAN METODE GERAKAN OBYEK UNTUK PENGAMBILAN CITRA DIGITAL PADA OBTION REMOTE VERSI 1.0
}

Astika Ayuningtyas, Agus Basukesti, NurCahyani Dewi Retnowati

Jurusan Teknik Informatika

Sekolah Tinggi Teknologi Adisutjipto Yogyakarta

informatika@stta.ac.id

\section{ABSTRACT}

Development of the world's information and communication technology-based growing rapidly. The development of these technologies has given rise to another dimension in human life, namely the need for computer use. Application of machine vision applications where a computer has the ability to understand the data in the form of image and make decisions based on data obtained from a real object, in this case is generated through the capture image from webcam.

The images (digital images) of a real object through a webcam can be done in many ways capture the object. In this research object retrieval using an object of activity is captured on the webcam through the motions of objects. Digital image acquisition is performed with the tool in the form of software (Obtion Remote Version 1.0). Obtion (Object Detection) method works with the system of comparison between that time frame the previous frame captured by the camera at the time of recording the object. Comparison of the difference in the frame will be accommodated in a place that will be used to support the execution of an object by counting the number of pixels that exceed the value of the difference in number of field values with regulator frame to frame changes in the location of the object motion

Obtion Remote Version 1.0 will take a digital image of the object with trigger object motion detection performed. Digital image acquisition (capture the object with a webcam) will be done automatically if the object has been successfully detected. The detected object will be stored automatically in the directory are executed as a digital image storage.

Keywords: Method of Object Motion, Digital Image, Obtion Remote.

\section{ABSTRAK}

Perkembangan dunia informasi dan komunikasi berbasis teknologi semakin pesat. Perkembangan teknologi tersebut telah melahirkan dimensi lain dalam sisi kehidupan manusia yaitu penggunaan kebutuhan akan komputer. Aplikasi mesin visi merupakan suatu aplikasi dimana komputer memiliki kemampuan untuk memahami data berupa image dan mengambil keputusan berdasarkan data yang didapat dari suatu obyek nyata, dalam hal ini adalah image yang dihasilkan melalui capture dari webcam.

Hasil gambar (citra digital) dari suatu obyek nyata melalui webcam dapat dilakukan dengan bermacam cara pengambilan obyek. Pada penelitian ini dilakukan pengambilan obyek dengan memanfaatkan aktivitas obyek yang tertangkap pada webcam yaitu melalui gerakan obyek. Pengambilan citra digital ini dilakukan dengan alat bantu yang berbentuk perangkat lunak (Obtion Remote Versi 1.0). Metode object detection (obtion) bekerja dengan sistem perbandingan antara frame saat itu dengan frame sebelumnya yang tertangkap kamera pada saat perekaman obyek. Perbandingan nilai selisih pada frame tersebut akan ditampung pada sebuah tempat yang nantinya akan digunakan untuk pendukung pengeksekusian obyek dengan 
menghitung banyaknya piksel yang nilai selisih jumlahnya melebihi nilai bidang frame dengan pengatur perubahan letak frame terhadap gerakan obyek.

Obtion Remote Versi 1.0 akan mengambil citra digital obyek dengan pemicu deteksi gerakan yang dilakukan obyek. Pengambilan citra digital (capture obyek dengan webcam) akan dilakukan secara otomatis apabila obyek telah berhasil terdeteksi. Hasil eksekusi obyek yang terdetksi akan tersimpan otomatis pada direktori yang dieksekusi sebagai tempat penyimpanan citra digital.

\section{Kata kunci : Metode Gerakan Obyek, Citra Digital, Obtion Remote.}

\section{Latar Belakang}

Perkembangan dunia informasi dan komunikasi berbasis teknologi semakin pesat. Perkembangan teknologi tersebut telah melahirkan dimensi lain dalam sisi kehidupan manusia yaitu penggunaan kebutuhan akan komputer. Salah satunya pada sisi perangkat lunak, bagian dari perangkat komputer ini menjadi bagian terpenting dalam perkembangan teknologi. Aplikasi mesin visi merupakan suatu aplikasi dimana komputer memiliki kemampuan untuk memahami data berupa image dan mengambil keputusan berdasarkan data yang didapat dari suatu obyek nyata, dalam hal ini adalah image yang dihasilkan melalui capture dari webcam.

Mendapatkan hasil gambar (citra digital) dari suatu obyek nyata melalui webcam dapat dilakukan dengan bermacam cara pengambilan obyek. Cara tersebut disesuaikan dengan tujuan pengambilan terhadap obyek yang ditangkap webcam. Pada penelitian ini dilakukan pengambilan obyek dengan memanfaatkan aktivitas obyek yang tertangkap pada webcam yaitu melalui gerakan obyek. Pengambilan citra digital ini dilakukan dengan alat bantu yang berbentuk perangkat lunak (software). Software tersebut (Obtion Remote Versi 1.0) akan membantu melakukan perekaman dan pendeteksian obyek dengan metode obtion (object detection). Metode object detection (obtion) bekerja dengan sistem perbandingan antara frame saat itu dengan frame sebelumnya yang tertangkap kamera pada saat perekaman obyek. Perbandingan nilai selisih pada frame tersebut akan ditampung pada sebuah tempat yang nantinya akan digunakan untuk pendukung pengeksekusian obyek dengan menghitung banyaknya piksel yang nilai selisih jumlahnya melebihi nilai bidang frame dengan pengatur perubahan letak frame terhadap gerakan obyek.

\section{Landasan Teori}

\section{Computer Vision}

Computer Vision adalah suatu aplikasi dengan metode dimana komputer mempunyai kemampuan untuk memahami data berupa image dan fungsi untuk mengolah data dan mengambil keputusan berdasarkan data yang didapat dari suatu obyek nyata, dalam hal ini adalah image (gambar) yang dihasilkan melalui capture dari webcam.

\section{Citra}

Citra adalah suatu kemiripan atau imitasi dari suatu obyek atau benda. Citra yang terlihat merupakan cahaya yang direfleksikan dari sebuah obyek. Sumber cahaya menerangi obyek, obyek memantulkan kembali sebagian dari berkas cahaya tersebut dan pantulan cahaya ditangkap oleh alat-alat optik, misalnya mata manusia, kamera, scanner, dsb, kemudian direkam. Citra yang tampak dalam matematis merupakan kumpulan nilai-nilai tertentu yang membentuk suatu pola berdasarkan keadaan yang telah dikondisikan. Citra sebagai keluaran dari suatu sistem perekaman data dapat bersifat optik berupa foto, analog berupa sinyal video seperti gambar pada 
monitor televisi, digital yang dapat langsung disimpan pada media penyimpanan magnetik (Idhawati, 2011).

Citra digital disimpan dalam format digital (dalam bentuk file). Hanya citra digital yang dapat diolah menggunakan komputer. Jenis citra lain jika ingin diolah menggunakan komputer harus terlebih dahulu citra tersebut diubah menjadi citra digital. Citra diskrit atau citra digital dihasilkan melalui proses digitalisasi terhadap citra kontinu. Contoh : kamera digital, scanner. Citra digital merupakan fungsi intensitas cahaya $\mathrm{f}(\mathrm{x}, \mathrm{y})$, dimana harga $\mathrm{x}$ dan $\mathrm{y}$ merupakan koordinat spasial dan harga fungsi tersebut pada setiap titik (x,y) merupakan tingkat kecemerlangan atau intensitas cahaya citra pada titik tersebut.

\section{Deteksi Gerakan}

Deteksi gerakan merupakan operasi dasar yang banyak digunakan dalam aplikasi Mesin Visi. Operasi ini digunakan untuk mendeteksi adanya gerakan dari suatu obyek pada daerah tangkapan kamera. Terdapat beberapa teknik untuk mendeteksi adanya gerakan dalam sebuah frame, yang termasuk kompleks adalah menggunakan teknik Optical Flow. Teknik optical flow tujuannya untuk membedakan antara daerah objek dengan daerah yang kosong, optical flow sangat terpengaruh oleh cahaya, biasanya optical flow ditandai oleh kotak-kotak kecil pada objek yang terdeteksi.

\section{Deteksi Obyek Terhadap Latar}

Deteksi obyek juga merupakan aplikasi dasar mesin visi yang biasanya dilanjutkan dengan operasi pengenalan pola atau klasifikasi. Dengan melakukan deteksi obyek, maka dapat diambil informasi piksel mana dalam frame yang ditangkap merupakan bagian dari suatu obyek dan bagian mana yang merupakan latar.

Salah satu cara yang dapat digunakan untuk mendeteksi obyek adalah dengan membandingkan frame pada saat itu dengan frame yang berisi pemandangan latar tanpa adanya obyek yang hendak dideteksi (alih-alih dibandingkan dengan frame sebelumnya).

\section{Piksel}

Piksel (picture element / unsur gambar) adalah titik-titik kecil. Gambar apapun yang tampak di layar komputer sebenarnya tersusun dari titik-titik kecil yang disebut piksel. Jika beberapa piksel diletakkan berderet, akan tampaklah suatu garis. Jadi semua garis, sehalus apapun tampaknya dilayar komputer, sebenarnya adalah deretan piksel. Sebuah piksel memang bisa dianggap sebagai sebuah titik, namun dalam kenyataannya, piksel-piksel lebih mirip dengan persegi panjang kecil yang tingginya tidak sebanding dengan lebarnya.

\section{Kontras}

Kontras suatu citra adalah perbedaan antara nilai piksel tergelap dengan piksel yang paling terang dalam citra. Citra dikatakan kontrasnya rendah jika perbedaan kecil, sedangkan kontras tinggi jika perbedaannya besar. Tidak semua perangkat keras pencitraan menghasilkan citra dengan kontras yang baik (biasanya kontras rendah), untuk itu perlu dilakukan operasi peningkatan kontras untuk citra.

Kontras yang optimal adalah jika perbedaan tersebut sesuai dengan kedalaman bit dari format citra. Misal citra keabuan 8 bit memiliki kontras optimal sebesar 255 karena piksel tergelap adalah hitam dengan nilai 0 dan paling terang putih dengan nilai 255 .

Operasi kontras merupakan operasi titik (hanya bergantung pada nilai piksel, bukan pada lokasi citra), dengan berbagai persamaan yang dapat diterapkan. Salah satu persamaan yang dapat digunakan adalah sebagai berikut : 


$$
\begin{aligned}
& R_{o}=\text { Gain }_{R} *\left(R_{i^{-}} \text {Center }_{R}\right)+\text { Center }_{R} \\
& G_{o}=\text { Gain }_{G} *\left(G_{i^{-}} \text {Center }_{G}\right)+\text { Center }_{G} \\
& B_{o}=\text { Gain }_{B} *\left(B_{i^{-}} \text {Center }_{B}\right)+\text { Center }_{B}
\end{aligned}
$$

Dimana Gain adalah faktor penguatan kontras sedangkan Center adalah pusat penguatan kontras. Kedua koefisien ini dapat seragam untuk semua elemen warna ataupun berbeda.

\section{Komponen Penangkap Frame Kamera}

Komponen standar dari Delphi tidak dapat digunakan untuk mengakses kamera digital atau webcam. Oleh karena itu, diperlukan komponen tambahan untuk menangkap (capture) citra atau frame dari webcam baik untuk penangkapan citra secara tunggal maupun dalam bentuk citra dinamik (multiframe).

Banyak komponen yang dapat digunakan untuk keperluan itu terdapat di internet. Namun, hampir semua komponen tersebut merupakan produk shareware yang umumnya memiliki beberapa kekurangan, yaitu :

1. Hanya dapat dipakai dalam waktu tertentu.

2. Dapat digunakan tanpa batasan waktu, tetapi komponen tersebut meninggalkan jejak dengan mencantumkan tulisan tertentu pada setiap frame yang ditangkap dari kamera.

Pembatasan waktu dan penambahan tulisan tersebut akan dihilangkan apabila sudah membeli lisensi dari pembuatnya.

Komponen JHVideoCap ini merupakan paket komponen yang dibuat oleh J.Huebler dari Jerman. JHVideoCap adalah produk yang bersifat freeware dan boleh digunakan untuk sembarang aplikasi tanpa harus membayar. Untuk menggunakan komponen JHVideoCap, tidak diperlukan lisensi sama sekali.

Paket JHVideoCap terdiri atas dua komponen yaitu :

a. TVideoCap yang digunakan untuk menagkap frame langsung dari webcam.

b. TVideoDisp, yang digunakan untuk menampilkan frame bitmap.

\section{Hasil Kuesioner Aktivasi Gerakan di Depan Komputer}

Penting untuk mengetahui seberapa aktif seseorang melakukan aktivitas gerakan pada saat aktivitas di depan komputer/laptop. Untuk itu di lakukan penyebaran kuesioner untuk mengambil kesimpulan seberapa aktif seseorang bergerak pada saat beraktivitas di depan komputer/laptop. Data tersebut dapat dijadikan acuan pemanfaatan metode deteksi gerakan.

Kuesioner terdiri dari dua pertanyaan yaitu pertanyaan terbuka dan tertutup. Dimana, $\mathrm{Ho}=\mathrm{P} 1=\mathrm{P} 2=0.5$ (Aktivitas gerakan seseorang di depan komputer/laptop adalah cenderung sering), dan $\mathrm{Ha}=\mathrm{P} 1 \neq \mathrm{P} 2 \neq 0.5$. 


\section{$\Rightarrow$ NPar Tests}

\begin{tabular}{|c|c|c|c|c|c|c|c|c|}
\hline \multicolumn{9}{|c|}{ Descriptive Statistics } \\
\hline & \multirow[b]{2}{*}{$N$} & \multirow[b]{2}{*}{ Mean } & \multirow[b]{2}{*}{ Std. Deviation } & \multirow[b]{2}{*}{ Minimum } & \multirow[b]{2}{*}{ Maximum } & \multicolumn{3}{|c|}{ Percentiles } \\
\hline & & & & & & 25 th & 50th (Median) & 75 th \\
\hline \begin{tabular}{|l|l} 
CENDRUNG \\
\end{tabular} & 30 & 87 & 35 & 0 & 1 & 1,00 & 1,00 & 1,00 \\
\hline
\end{tabular}

\begin{tabular}{|c|c|c|c|c|c|c|}
\hline \multicolumn{7}{|c|}{ Binomial Test } \\
\hline & & Category & $\mathrm{N}$ & $\begin{array}{l}\text { Observed } \\
\text { Prop. }\end{array}$ & Test Prop. & $\begin{array}{c}\text { Asymp. Sig. } \\
\text { (2-tailed) }\end{array}$ \\
\hline \multirow[t]{3}{*}{ CENDRUNG } & Group 1 & 1 & 26 & .87 & \multirow[t]{3}{*}{.50} & \multirow[t]{3}{*}{, $000^{\mathrm{a}}$} \\
\hline & Group 2 & 0 & 4 &, 13 & & \\
\hline & Total & & 30 & 1,00 & & \\
\hline
\end{tabular}

a. Based on Z Approximation.

Gambar 1 Hasil Kuesioner Dengan Binomial Test

Hasil kuesioner yang tertera pada gambar 1, nilai sigma lebih dari 0.05 maka kondisi yang diterima adalah Ho. Analisa kesimpulan menunjukkan bahwa Aktivitas gerakan seseorang di depan komputer adalah cenderung

\section{Perancangan Infrastruktur Sistem}

Pada gambar 2 perancangan alur program memberikan gambaran secara visual melalui sebuah gambar untuk dapat memahami bagaimana sistem bekerja dalam pengambilan citra digital obyek dengan pendeteksian gerakan yang dilakukan obyek. Sistem berkolaborasi bersama melakukan fungsinya untuk mendeteksi obyek.

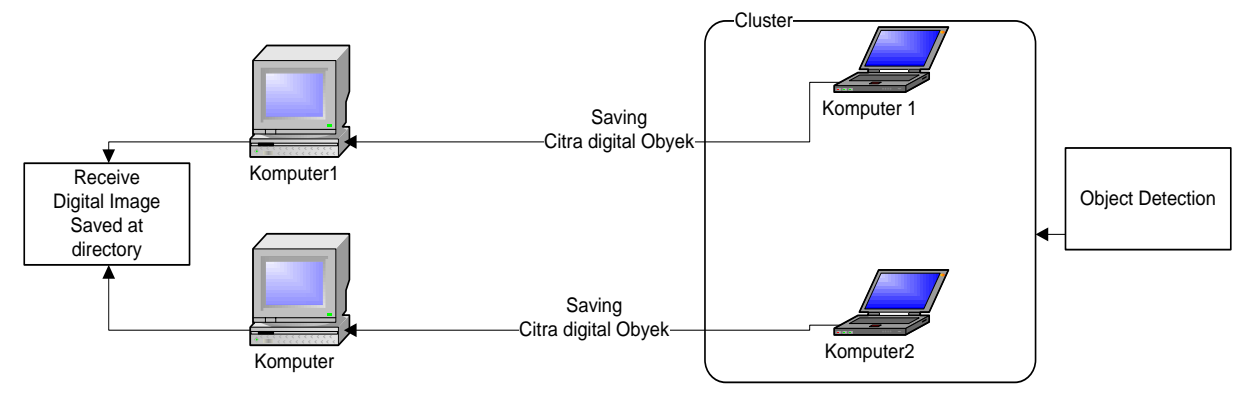

Gambar 2 Infrastruktur Sistem

Pada gambar 2, dapat dilihat komputer1 dan komputer2 melakukan proses pengambilan citra digital obyek dengan menggunakan Obtion Remote Versi 1.0. Ketika sistem Obtion Remote telah aktif berjalan, akan melakukan proses perekaman obyek dan peng-capture-an obyek dengan pendeteksian adanya gerakan pada obyek tersebut. Setelah proses pendeteksian gerakan obyek terdeteksi, maka akan dilakukan eksekusi pengambilan gambar obyek yang berupa citra digital melalui proses capture webcam dan selanjutnya melakukan penyimpanan hasil tangkapan obyek yang terdeteksi berupa citra digital ke komputer dimana sistem obtion berjalan. Komputer akan menyimpan hasil deteksi obyek berupa citra digital pada direktori khusus yang ditunjuk di 
komputer tersebut. Proses deteksi obyek dilakukan secara otomatis selama sistem deteksi obyek di komputer aktif.

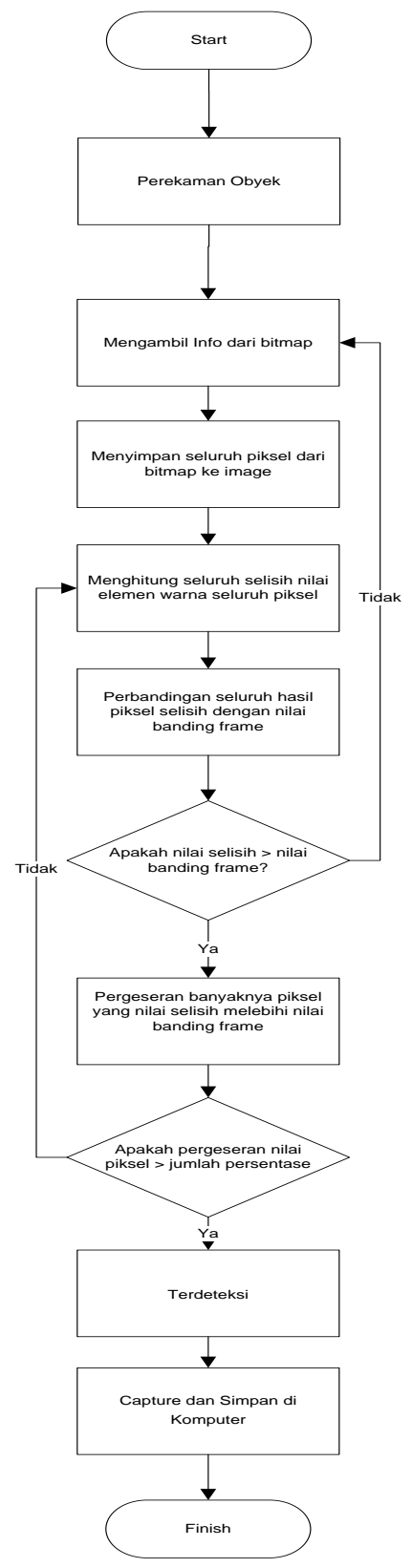

Gambar 3 Perancangan Flowchart Pengambilan Object Detection

\section{Algoritma}

Algoritma merupakan konsep dasar dari sebuah program. Sedangkan dalam pembuatan algoritma diperlukan daya nalar yang baik dan logis. Dengan pertimbangan, sebuah algoritma terdiri dari langkah-langkah penyelesaikan masalah. Langkah-langkah algoritma dibatasi oleh obyek masalah yang dihadapi. Pada gambar 3, merupakan algoritma proses pendeteksian obyek 
dimana dalam obyek masalah yang dihadapi adalah bagaimana melakukan peng-capture-an dengan obyek pendeteksinya adalah gerakan obyek yang dideteksi tersebut

\section{Pseucode}

Pseucode perancangan Obtion Remote adalah sebagai berikut :

1. Melakukan pengaktifan preview

$$
\begin{array}{ll}
\text { VideoCap1. DriverIndex } & =0 ; \\
\text { VideoCap1. Driveropen } & =\text { true; } \\
\text { VideoCap1. VideoPreview } & \text { true; }
\end{array}
$$

2. Melakukan perekaman obyek active front object dan pengambilan info bitmap

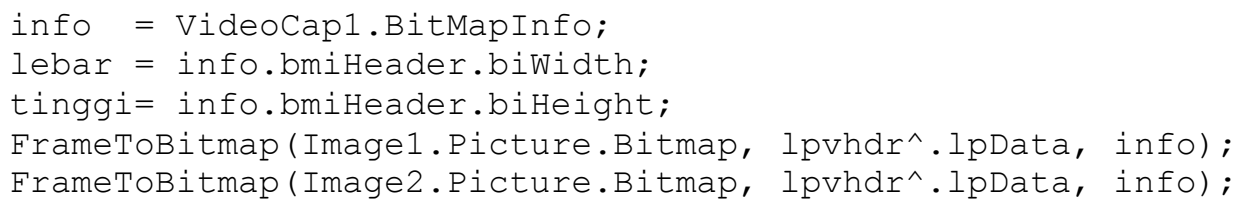

4. Melakukan perhitungan pergeseran dan perbandingan nilai persentase

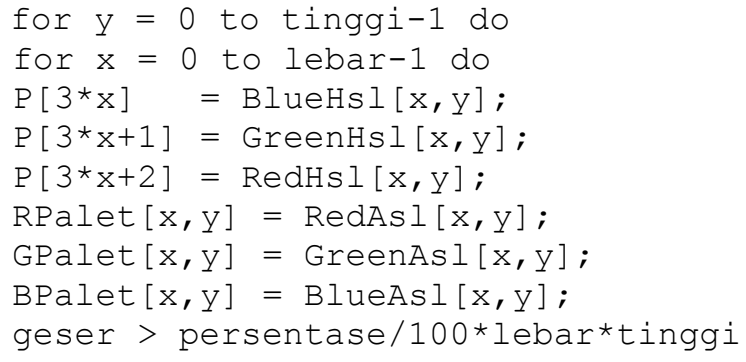




\section{Pengujian dan Analisa}

Pengujian aplikasi Obtion Remote Versi 1.0 dilakukan pada jaringan localhost, jaringan lokal (LAN Kabel dan WiFi), dan jaringan internet. Obtion Remote Versi 1.0 menggunakan dua komputer. Langkah pertama, mempersiapkan alat-alat yang diperlukan (yang telah disebutkan diatas) dan setelah terpasang pada komputer yang akan diujicobakan, selanjutnya proses instalasi Obtion Remote Versi 1.0 pada komputer server dan pada komputer yang bertindak sebagai client (lihat gambar 4.1 sampai gambar 4.3). Aplikasi di komputer server hanya berfungsi sebagai media pengujian pengiriman hasil pengambilan citra digital obyek yang berhasil terdeteksi dan tersimpan otomatis di client. Pengujian pengiriman hasil tersebut dilakukan pada beberapa infrastruktur jaringan (localhost, LAN Kabel, WiFi, internet). Sedangkan komputer client digunakan untuk menguji implementasi dari metode pengambilan obyek menggunakan deteksi gerakan obyek.

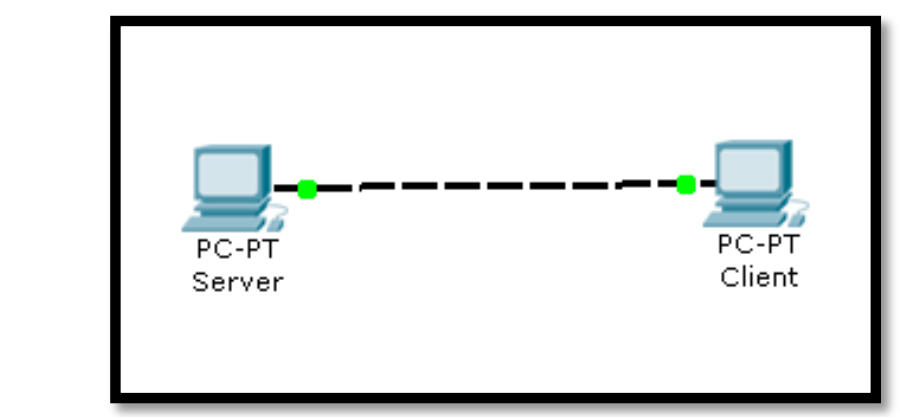

Gambar 4 Perancangan Simulasi Uji Coba

\section{Uji Coba Deteksi Obyek}

Pada Obtion Remote Versi 1.0 tampilan awalnya berupa Form Obtion (lihat gambar 5). Form utama yang melakukan proses pengambilan citra digital obyek melalui deteksi gerakan yang dilakukan obyek tersebut selama proses perekaman obyek. Sistem Obtion melakukan pengambilan obyek otomatis dengan metode pengambilan berdasarkan gerakan obyek. Gerakan obyek yang dideteksi adalah gerakan obyek terhadap dirinya sendiri. Setelah gerakan obyek berhasil terdeteksi, akan dilakukan pengambilan obyek berupa citra digital melalui hasil perekaman obyek pada webcam. Hasil dari pengambilan obyek akan langsung tersimpan pada komputer yang menjalankan sistem Obtion tersebut. 


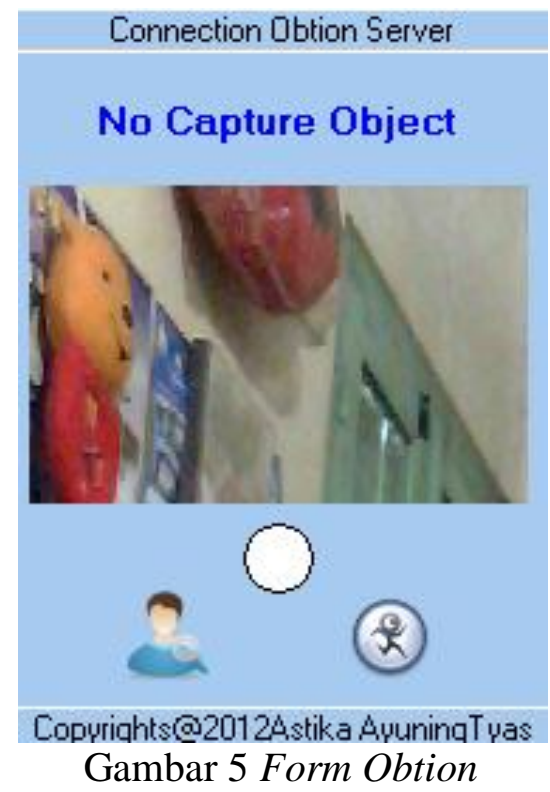

Pada gambar 5, tampilan ketika awal dilakukannya proses pengambilan citra digital obyek, kondisi lampu indikator masih berwarna putih (tidak ada obyek yang terdeteksi) dan informasi label "No Capture Object" (belum dilakukan eksekusi pengambilan obyek).

Selama proses perekaman obyek, apabila terdeteksi adanya gerakan obyek akan dilakukan pengambilan obyek berupa citra digital melalui proses peng-capture-an dengan webcam. Proses pendeteksian obyek dapat terlihat pada gambar 6, dimana kondisi awal informasi belum adanya obyek yang terdeteksi. Setelah terdeteksi gerakan yang dilakukan obyek, kondisi lampu indikator berwarna merah (obyek terdeteksi) dan informasi label "Yes Capture Object" (dilakukan eksekusi pengambilan obyek dan menyimpannya langsung pada komputer yang menjalankan sistem Obtion). Pada gambar 7 terdapat proses pendeteksian dari gerakan yang dilakukan obyek. Dari hasil perekaman obyek (preview) sampai transformasi informasi bitmap dalam buffer kamera yang tertampung dalam frame terhadap seluruh total piksel yang telah mengalami proses modifikasi perhitungan. Gerakan obyek akan terbaca apabila ada perubahan nilai letak piksel keseluruhan yang ada dalam frame. Hasil dari pengambilan citra digital obyek dapat dilihat pada gambar 8. Ukuran citra digital yang dihasilkan setiap proses pengambilan obyek adalah sama (1.17 MB). Ukuran tersebut dipengaruhi oleh template frame yang digunakan pada komponen JHVideoCap dalam format matriks 640x480.

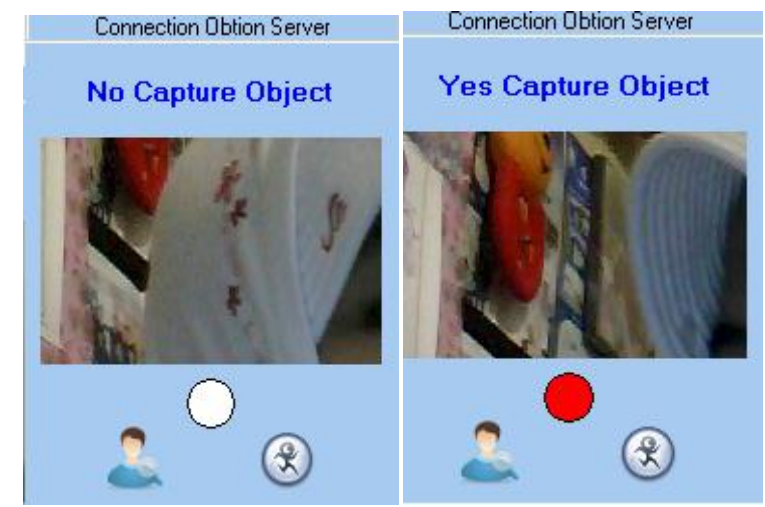

Gambar 6 Proses Deteksi dan Pengambilan Obyek 

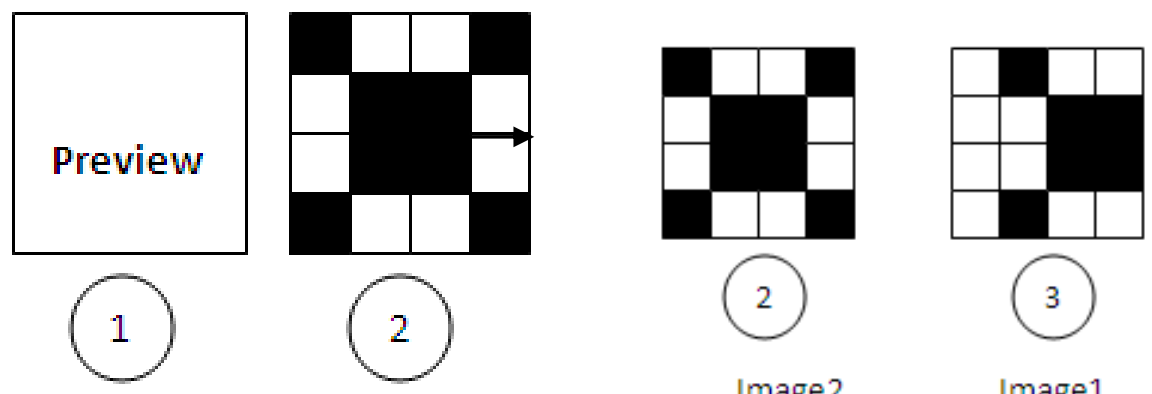

Gambar 7 Proses Deteksi Gerakan Obyek

Image1

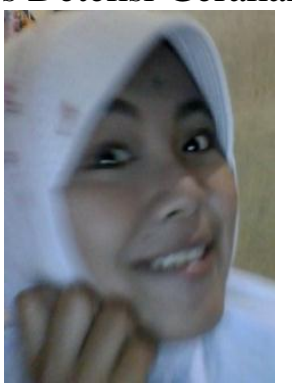

\section{Uji Coba Obyek}

Gambar 8 Hasil Deteksi dan Pengambilan Obyek

Pada uji coba obyek dilakukan beberapa pengambilan macam obyek. Uji coba bermacam obyek ini dilakukan untuk mengetahui keakuratan metode pembacaan gerakan pada obyek yang sedang dideteksi dan akan dilakukan proses pengambilan citra digital apabila gerakan yang dilakukan obyek tersebut terdeteksi. Hasil dari pengujian bermacam gerakan obyek ini dapat dilihat pada tabel 1 .

Tabel 1 Hasil Uji Coba Obyek

\begin{tabular}{|c|c|c|c|c|c|}
\hline No & Obyek & Keterangan Gerakan & Hasil & Waktu & IP/Hostname \\
\hline 1. & Manusia & $\begin{array}{c}\text { wajah menghadap webcam, } \\
\text { diam saja }\end{array}$ & $\begin{array}{c}\text { Not } \\
\text { Detected }\end{array}$ & $\begin{array}{l}14: 02: 22- \\
14: 02.29\end{array}$ & $\begin{array}{c}\text { 192.168.1.8 } \\
\text { Royale }\end{array}$ \\
\hline 2. & Manusia & $\begin{array}{c}\text { wajah menghadap ke } \\
\text { samping, dan bergerak } \\
\text { geleng sedikit }\end{array}$ & Detected & $\begin{array}{l}14: 08: 08- \\
14: 08: 12\end{array}$ & $\begin{array}{l}\text { 192.168.1.8 } \\
\text { Royale }\end{array}$ \\
\hline 3. & $\begin{array}{l}\text { Boneka } \\
\text { Beruang }\end{array}$ & $\begin{array}{l}\text { Obyek boneka di depan } \\
\text { webcam, digerak-gerakan } \\
\text { bonekanya }\end{array}$ & Detected & $\begin{array}{l}14: 09: 20- \\
14: 09: 28\end{array}$ & $\begin{array}{l}\text { 192.168.1.8 } \\
\text { Royale }\end{array}$ \\
\hline 4. & $\begin{array}{l}\text { Boneka } \\
\text { Beruang }\end{array}$ & $\begin{array}{l}\text { Obyek boneka di depan } \\
\text { webcam, tanpa digerak- } \\
\text { gerakan bonekanya }\end{array}$ & $\begin{array}{c}\text { Not } \\
\text { Detected }\end{array}$ & $\begin{array}{l}14: 10: 46- \\
14: 10: 53\end{array}$ & $\begin{array}{l}\text { 192.168.1.8 } \\
\text { Royale }\end{array}$ \\
\hline 5. & Boneka Tupai & $\begin{array}{l}\text { Di depan webcam dan } \\
\text { bergerak-gerak }\end{array}$ & Detected & $\begin{array}{l}14: 11: 06- \\
14: 11: 15\end{array}$ & $\begin{array}{l}\text { 192.168.1.8 } \\
\text { Royale }\end{array}$ \\
\hline 6. & $\begin{array}{l}\text { Manusia } \\
\text { dengan } \\
\text { topeng }\end{array}$ & $\begin{array}{c}\text { Di depan webcam, kepala } \\
\text { bergeleng }\end{array}$ & Detected & $\begin{array}{l}14: 12: 54- \\
14: 12: 59\end{array}$ & $\begin{array}{l}\text { 192.168.1.8 } \\
\text { Royale }\end{array}$ \\
\hline 7. & $\begin{array}{l}\text { Manusia } \\
\text { dengan } \\
\text { topeng }\end{array}$ & $\begin{array}{l}\text { Di depan webcam dan } \\
\text { menutupi webcam }\end{array}$ & $\begin{array}{c}\text { Not } \\
\text { Detected }\end{array}$ & $\begin{array}{l}14: 17: 11- \\
14: 18: 11\end{array}$ & $\begin{array}{l}\text { 192.168.1.8 } \\
\text { Royale }\end{array}$ \\
\hline
\end{tabular}




\begin{tabular}{|c|c|c|c|c|c|}
\hline 8. & Hewan & Di depan webcam dan & Detected & $14: 18: 20-$ & 192.168 .1 .8 \\
Rergerak-gerak & & $14: 18: 28$ & $\begin{array}{c}192.168 .1 .8 \\
\text { Royale }\end{array}$ \\
\hline 9. & Hewan Ayam & $\begin{array}{c}\text { Di depan webcam dan } \\
\text { bergerak-gerak }\end{array}$ & Detected & $\begin{array}{c}14: 19: 30- \\
14: 19: 35\end{array}$ & $\begin{array}{c}192.168 .1 .8 \\
\text { Royale }\end{array}$ \\
\hline 10. & Hewan & Di depan webcam dan & Detected & $14: 20: 05-$ & $14: 20: 08$ \\
& Kelinci & bergerak-gerak & & & \\
\hline
\end{tabular}

\section{Uji Coba Jaringan}

Pengujian jaringan digunakan untuk menguji proses pengiriman hasil deteksi obyek berupa citra digital obyek. Dimana dalam proses pengujian menggunakan salah satu bagian fungsi aplikasi Obtion Remote Versi 1.0 yang dijalankan secara terpisah dengan proses pendeteksian dan pengambilan obyek. Sistem pengiriman tersebut dijalankan secara terpisah dan berada pada komputer yang bertindak sebagai server (lihat gambar 9)., sedangkan client (sistem yang melakukan proses pendeteksian) akan memberikan tampilan informasi komunikasi dengan server beserta keterangan dalam proses pengiriman citra digital (lihat gambar 10).

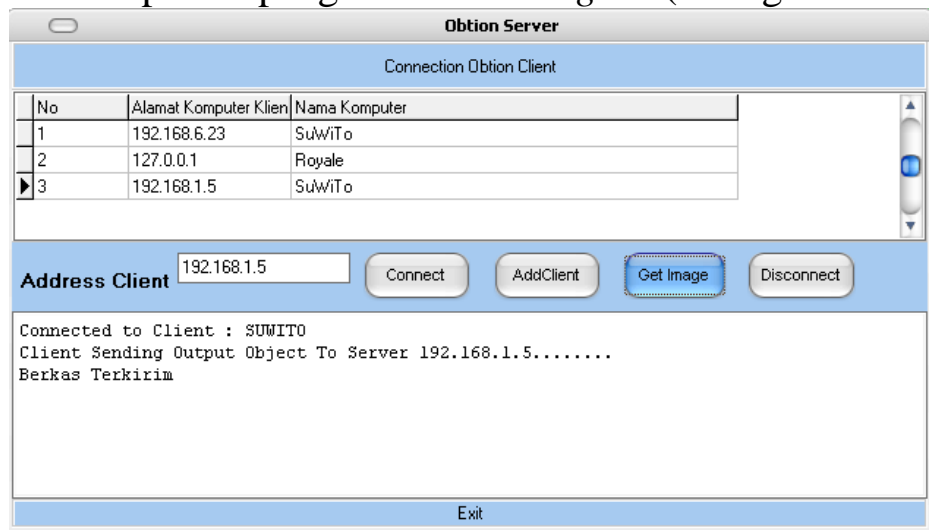

Gambar 9 Implementasi Sistem Pengujian Jaringan Di Server

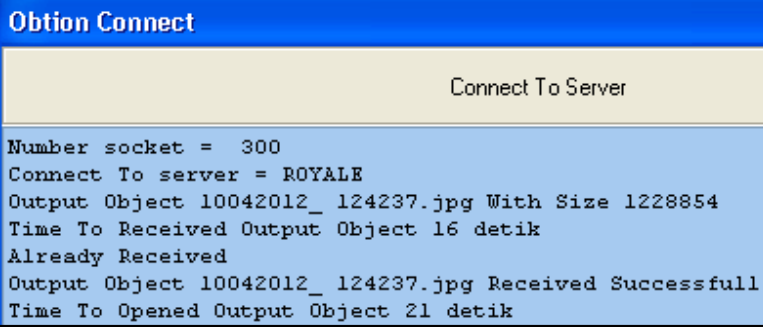

\section{Uji Coba Jaringan Localhost}

\section{Gambar 10 Implementasi Sistem Pengujian Jaringan Di Client}

Pada uji coba jaringan localhost, hasil dari proses pengambilan citra digital obyek dengan deteksi gerakan yang dilakukan obyek akan dikirim ke server pada jaringan localhost. Pada tabel 2 adalah hasil dari uji coba pengiriman citra digital yang dilakukan pada jaringan localhost.

Tabel 2 Hasil Uji Coba Jaringan Localhost

\begin{tabular}{|l|c|c|c|c|c|}
\hline No. & File Image & Size Image & $\begin{array}{c}\text { File Received } \\
\text { (Seconds) }\end{array}$ & $\begin{array}{c}\text { File Open } \\
\text { (Seconds) }\end{array}$ & $\begin{array}{c}\text { Interval Seconds } \\
\text { (Received-Open) }\end{array}$ \\
\hline 1. & $10042012 \_124232 . j p g$ & $1228854(1.17 \mathrm{MB})$ & 8 & 10 & 2 \\
\hline 2. & $10042012 \_124234 . j p g$ & $1228854(1.17 \mathrm{MB})$ & 6 & 8 & 2 \\
\hline
\end{tabular}




\begin{tabular}{|l|l|l|c|c|c|}
\hline 3. & $10042012 \_124245 . j p g$ & $1228854(1.17 \mathrm{MB})$ & 9 & 11 & 2 \\
\hline 4. & $10042012 \_124247 . j p g$ & $1228854(1.17 \mathrm{MB})$ & 8 & 10 & 2 \\
\hline 5. & $10042012 \_124256 . j p g$ & $1228854(1.17 \mathrm{MB})$ & 12 & 14 & 2 \\
\hline 6. & $10042012 \_124301 . j p g$ & $1228854(1.17 \mathrm{MB})$ & 7 & 9 & 2 \\
\hline 7. & $10042012 \_124310 . j p g$ & $1228854(1.17 \mathrm{MB})$ & 7 & 9 & 2 \\
\hline 8. & $10042012 \_130121 . j p g$ & $1228854(1.17 \mathrm{MB})$ & 6 & 8 & 2 \\
\hline 9. & $10042012 \_130127 . j p g$ & $1228854(1.17 \mathrm{MB})$ & 6 & 9 & 3 \\
\hline 10. & $10042012 \_130130 . j p g$ & $1228854(1.17 \mathrm{MB})$ & 6 & 8 & 2 \\
\hline 11. & $10042012 \_130133 . j p g$ & $1228854(1.17 \mathrm{MB})$ & 6 & 8 & 2 \\
\hline 12. & $10042012 \_130142 . j p g$ & $1228854(1.17 \mathrm{MB})$ & 6 & 8 & 2 \\
\hline 13. & $10042012 \_130146 . j p g$ & $1228854(1.17 \mathrm{MB})$ & 7 & 9 & 2 \\
\hline 14. & $10042012 \_130216 . j p g$ & $1228854(1.17 \mathrm{MB})$ & 7 & 9 & 2 \\
\hline 15. & $10042012 \_130223 . j p g$ & $1228854(1.17 \mathrm{MB})$ & 7 & 9 & 2 \\
\hline
\end{tabular}

\section{Uji Coba Jaringan LAN (Kabel)}

Pada uji coba jaringan LAN dengan kabel, hasil dari proses pengambilan citra digital obyek dengan deteksi gerakan yang dilakukan obyek akan dikirim ke server pada jaringan LAN (kabel). Pada tabel 3 adalah hasil dari uji coba pengiriman citra digital yang dilakukan pada jaringan LAN (kabel).

Tabel 3 Hasil Uji Coba Jaringan LAN (Kabel)

\begin{tabular}{|l|l|l|c|c|c|}
\hline No. & \multicolumn{1}{|c|}{ File Image } & Size Image & $\begin{array}{c}\text { File Received } \\
\text { (Seconds) }\end{array}$ & $\begin{array}{c}\text { File Open } \\
\text { (Seconds) }\end{array}$ & $\begin{array}{c}\text { Interval Seconds } \\
\text { (Received-Open) }\end{array}$ \\
\hline 1. & $10042012 \_124232 . j p g$ & $1228854(1.17 \mathrm{MB})$ & 13 & 14 & 1 \\
\hline 2. & $10042012 \_124234 . j p g$ & $1228854(1.17 \mathrm{MB})$ & 15 & 17 & 2 \\
\hline 3. & $10042012 \_124245 . j p g$ & $1228854(1.17 \mathrm{MB})$ & 8 & 10 & 1 \\
\hline 4. & $10042012 \_124247 . j p g$ & $1228854(1.17 \mathrm{MB})$ & 12 & 13 & 3 \\
\hline 5. & $10042012 \_124256 . j p g$ & $1228854(1.17 \mathrm{MB})$ & 10 & 13 & 2 \\
\hline 6. & $10042012 \_124301 . j p g$ & $1228854(1.17 \mathrm{MB})$ & 8 & 10 & 2 \\
\hline 7. & $10042012 \_124310 . j p g$ & $1228854(1.17 \mathrm{MB})$ & 7 & 9 & 1 \\
\hline 8. & $10042012 \_130121 . j p g$ & $1228854(1.17 \mathrm{MB})$ & 8 & 9 & 2 \\
\hline 9. & $10042012 \_130127 . j p g$ & $1228854(1.17 \mathrm{MB})$ & 8 & 10 & 2 \\
\hline 10. & $10042012 \_130130 . j p g$ & $1228854(1.17 \mathrm{MB})$ & 8 & 10 & 2 \\
\hline 11. & $10042012 \_130133 . j p g$ & $1228854(1.17 \mathrm{MB})$ & 14 & 16 & 3 \\
\hline 12. & $10042012 \_130142 . j p g$ & $1228854(1.17 \mathrm{MB})$ & 9 & 11 & 11 \\
\hline 13. & $10042012 \_130146 . j p g$ & $1228854(1.17 \mathrm{MB})$ & 8 & 10 & \\
\hline 14. & $10042012 \_130216 . j p g$ & $1228854(1.17 \mathrm{MB})$ & 7 & 12 & 2 \\
\hline 15. & $10042012 \_130223 . j p g$ & $1228854(1.17 \mathrm{MB})$ & 10 & & 2 \\
\hline
\end{tabular}

\section{Uji Coba Jaringan LAN (WiFi)}

Pada uji coba jaringan LAN (WiFi), hasil dari proses pengambilan citra digital obyek dengan deteksi gerakan yang dilakukan obyek akan dikirim ke server pada jaringan LAN (WiFi). Pada tabel 4 adalah hasil dari uji coba pengiriman citra digital yang dilakukan pada jaringan LAN (WiFi).

Tabel 4 Hasil Uji Coba Jaringan LAN (WiFi)

\begin{tabular}{|l|c|c|c|c|c|}
\hline No. & File Image & Size Image & $\begin{array}{c}\text { File Received } \\
\text { (Seconds) }\end{array}$ & $\begin{array}{c}\text { File Open } \\
\text { (Seconds) }\end{array}$ & $\begin{array}{c}\text { Interval Seconds } \\
\text { (Received-Open) }\end{array}$ \\
\hline 1. & $10042012 \_124232 . j p g$ & $1228854(1.17 \mathrm{MB})$ & 15 & 18 & 3 \\
\hline 2. & $10042012 \_124234 . j p g$ & $1228854(1.17 \mathrm{MB})$ & 19 & 24 & 5 \\
\hline 3. & $10042012 \_124245 . j p g$ & $1228854(1.17 \mathrm{MB})$ & 25 & 27 & 2 \\
\hline 4. & $10042012 \_124247 . j p g$ & $1228854(1.17 \mathrm{MB})$ & 29 & 30 & 1 \\
\hline 5. & $10042012 \_124256 . j p g$ & $1228854(1.17 \mathrm{MB})$ & 31 & 32 & 1 \\
\hline
\end{tabular}




\begin{tabular}{|l|l|l|l|l|l|}
\hline 6. & $10042012 \_124301 . j p g$ & $1228854(1.17 \mathrm{MB})$ & 33 & 34 & 1 \\
\hline 7. & $10042012 \_124310 . j p g$ & $1228854(1.17 \mathrm{MB})$ & 30 & 31 & 1 \\
\hline 8. & $10042012 \_130121 . j p g$ & $1228854(1.17 \mathrm{MB})$ & 28 & 30 & 2 \\
\hline 9. & $10042012 \_130127 . j p g$ & $1228854(1.17 \mathrm{MB})$ & 26 & 28 & 2 \\
\hline 10. & $10042012 \_130130 . j p g$ & $1228854(1.17 \mathrm{MB})$ & 25 & 27 & 2 \\
\hline 11. & $10042012 \_130133 . j p g$ & $1228854(1.17 \mathrm{MB})$ & 30 & 32 & 2 \\
\hline 12. & $10042012 \_130142 . j p g$ & $1228854(1.17 \mathrm{MB})$ & 29 & 31 & 1 \\
\hline 13. & $10042012 \_130146 . j p g$ & $1228854(1.17 \mathrm{MB})$ & 28 & 29 & 1 \\
\hline 14. & $10042012 \_130216 . j p g$ & $1228854(1.17 \mathrm{MB})$ & 25 & 26 & 1 \\
\hline 15. & $10042012 \_130223 . j p g$ & $1228854(1.17 \mathrm{MB})$ & 27 & 28 & \\
\hline
\end{tabular}

\section{Uji Coba Jaringan Internet}

Pada uji coba jaringan internet, hasil dari proses pengambilan citra digital obyek dengan deteksi gerakan yang dilakukan obyek akan dikirim ke server pada jaringan internet. Pada tabel 5 adalah hasil dari uji coba pengiriman citra digital yang dilakukan pada jaringan internet.

Tabel 5 Hasil Uji Coba Jaringan Internet

\begin{tabular}{|l|l|l|c|c|c|}
\hline No. & \multicolumn{1}{|c|}{ File Image } & Size Image & $\begin{array}{c}\text { File Received } \\
\text { (Seconds) }\end{array}$ & $\begin{array}{c}\text { File Open } \\
\text { (Seconds) }\end{array}$ & $\begin{array}{c}\text { Interval Seconds } \\
\text { (Received-Open) }\end{array}$ \\
\hline 1. & $10042012 \_124232 . j p g$ & $1228854(1.17 \mathrm{MB})$ & 19 & 23 & 4 \\
\hline 2. & $10042012 \_124234 . j p g$ & $1228854(1.17 \mathrm{MB})$ & 28 & 32 & 4 \\
\hline 3. & $10042012 \_124245 . j p g$ & $1228854(1.17 \mathrm{MB})$ & 39 & 41 & 4 \\
\hline 4. & $10042012 \_124247 . j p g$ & $1228854(1.17 \mathrm{MB})$ & 48 & 52 & 3 \\
\hline 5. & $10042012 \_124256 . j p g$ & $1228854(1.17 \mathrm{MB})$ & 57 & 60 & 2 \\
\hline 6. & $10042012 \_124301 . j p g$ & $1228854(1.17 \mathrm{MB})$ & 65 & 67 & 3 \\
\hline 7. & $10042012 \_124310 . j p g$ & $1228854(1.17 \mathrm{MB})$ & 73 & 76 & 3 \\
\hline 8. & $10042012 \_130121 . j p g$ & $1228854(1.17 \mathrm{MB})$ & 81 & 84 & 2 \\
\hline 9. & $10042012 \_130127 . j p g$ & $1228854(1.17 \mathrm{MB})$ & 89 & 91 & 3 \\
\hline 10. & $10042012 \_130130 . j p g$ & $1228854(1.17 \mathrm{MB})$ & 97 & 100 & 2 \\
\hline 11. & $10042012 \_130133 . j p g$ & $1228854(1.17 \mathrm{MB})$ & 104 & 106 & 2 \\
\hline 12. & $10042012 \_130142 . j p g$ & $1228854(1.17 \mathrm{MB})$ & 112 & 114 & 124 \\
\hline 13. & $10042012 \_130146 . j p g$ & $1228854(1.17 \mathrm{MB})$ & 120 & 13 & 3 \\
\hline 14. & $10042012 \_130216 . j p g$ & $1228854(1.17 \mathrm{MB})$ & 130 & 133 & 4 \\
\hline 15. & $10042012 \_130223 . j p g$ & $1228854(1.17 \mathrm{MB})$ & 138 & 142 & \\
\hline
\end{tabular}

\section{Analisa Pendeteksian Obyek Dan Pengambilan Citra Digital Obyek}

Analisa yang dilakukan pada aplikasi Obtion Remote Versi 1.0 pada penerapan metode pengambilan obyek (citra digital) dengan deteksi gerakan obyek terhadap dirinya sendiri. Mendeteksi adanya gerakan obyek adalah dengan membandingkan setiap piksel dalam sebuah frame dengan piksel pada posisi yang sama dalam frame sebelumnya (lihat gambar 6). Apabila tidak ada obyek yang bergerak dalam frame tersebut, maka hasil perbandingan akan memberikan hasil yang relatif kecil.

\section{Analisa Pendeteksian Bermacam Gerakan Obyek}

Mendeteksi dengan bermacam obyek tidak mempengaruhi proses pendeteksian jenis obyek yang bergerak. Semua obyek dapat terdeteksi jika melakukan gerakan selama proses perekaman obyek dengan webcam. Hal tersebut dikarenakan metode yang digunakan adalah perbandingan setiap piksel dalam sebuah frame dengan piksel pada posisi yang sama dalam frame sebelumnya. Spesifik obyek yang tertangkap dalam proses perekaman tidak menjadi bahan perbandingan. Karena info yang diambil dalam buffer kamera hanyalah info tempat keseluruhan letak piksel terhadap frame. Dimana sebelumnya dilakukan perhitungan banyaknya piksel yang nilai selisih jumlahnya melebihi nilai bidang frame dengan pengatur perubahan letak frame 
terhadap gerakan obyek. Sehingga apapun obyek yang direkam pada webcam melakukan aktivitas (gerakan) akan dapat terdeteksi.

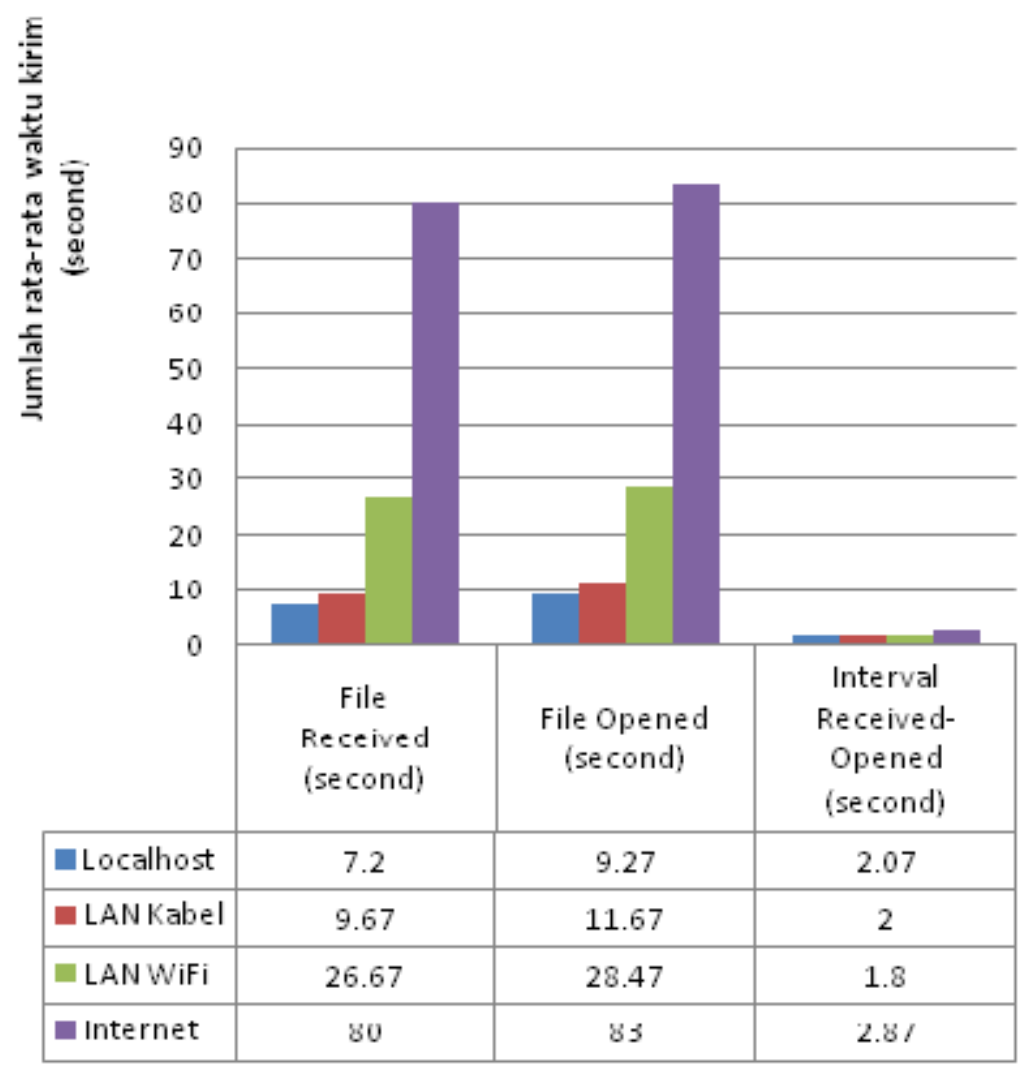

Gambar 11 Hasil Pengiriman Citra Digital Obyek di Jaringan

Pada gambar 11, semakin ke kanan grafik menunjukkan waktu yang dibutuhkan semakin banyak. Untuk area localhost dibutuhkan waktu paling sedikit karena transfer data masih pada satu komputer saja (hanya berpindah direktori). Waktu transfer data pada jaringan LAN kabel dan LAN WiFi menghasilkan perbedaan yang cukup signifikan, hal ini dipengaruhi oleh media dalam jaringan yang digunakan. Waktu transfer paling lama ditunjukkan pada hasil uji coba yang dilakukan pada jaringan internet, beberapa faktor seperti trafik kecepatan, jumlah kuota akses, dll mempengaruhi proses pengiriman.

\section{Kesimpulan}

Dalam melakukan pembuatan dan pengujian aplikasi Obtion Remote Versi 1.0 ini terdapat beberapa kesimpulan yang dapat diambil, diantaranya adalah :

1. Aplikasi Obtion Remote Versi 1.0 digunakan untuk pengambilan obyek berupa citra digital dengan menerapkan metode deteksi gerakan yang dilakukan obyek.

2. Metode deteksi gerakan obyek mendeteksi berbagai obyek apapun yang melakukan gerakan di depan webcam yang sedang dilakukan proses perekaman dan pendeteksian secara otomatis selama sistem aktif berjalan.

3. Hasil dari pendeteksian obyek berupa citra digital obyek langsung tersimpan pada komputer client yang menjalankan sistem obtion dan dikirimkan ke server dengan waktu transfernya bergantung dengan media jaringan yang diujikan. 
4. Kelemahan aplikasi Obtion Remote Versi 1.0 adalah ketergantungan terhadap komponen yang digunakan yaitu JHVideoCap sehingga mempengaruhi dalam proses pendeteksian obyek dan pengambilan citra digital obyek karena terdapat fungsi-fungsi komponen yang bersifat read only.

\section{Saran}

Adapun saran yang diberikan pada penelitian ini adalah sebagai berikut :

1. Dalam pengembangannya ke depan, metode deteksi gerakan obyek dalam pengambilan citra digital obyek dapat dispesifikkan pada jenis obyek tertentu dan gerakan bagian obyek tertentu (seperti face detection).

2. Obtion Remote Versi 1.0 dengan menerapkan deteksi gerakan obyek dapat menjadi ide awal untuk mengembangkan aplikasi dibidang forensik sebagai solusi untuk IT forensik mendapatkan bukti pengambilan obyek tertentu melalui kamera.

\section{Daftar Pustaka}

Achmad, Balza, 2011, Pemrograman Delphi untuk Aplikasi Mesin Visi menggunakan Webcam, Gava Media, Yogyakarta.

Fadlisyah, Rizal, 2011, Pemrograman Computer Vision pada Video menggunakan Delphi+VisionLab VCL 4.0.1, Graha Ilmu, Yogyakarta.

Suarna, Nana, 2007, Pengantar LAN (Local Area Network), Yrama Widya, Bandung.

Agushinta R D 2008, perbandingan kinerja metode deteksi tepi.pdf, http://repository.gunadarma.ac.id:8000/1851/1/UGArtikelDewiAR_edit.pdf, $\quad$ diakses tanggal 27 Desember 2011

Shinta, dkk 2009, aplikasi webcam untuk mendeteksi gerakan suatu objek.pdf, http://eprints.undip.ac.id/25283/1/2._Makalah_L2F002577.pdf, diakses tanggal 27 Desember 2011

Prayogi S 2009, sistem deteksi wajah.pdf, http://repo.eepis-its.edu/474/1/854.pdf, diakses tanggal 27 Desember 2011. 